\title{
AYAT-AYAT DOA DALAM AL QUR'AN PRESPEKTIF MAKNA DASAR DAN RELASIONAL
}

\author{
Abdul Wahab Rosyidi
}

Email: aw_rosyidi@yahoo.co.id

Fakultas Humaniora dan Budaya Universitas Islam Negeri Maulana Malik Ibrahim Malang Alamat Korespondensi: Jalan Gajayana 50 Malang, Telp/Fax (0341) 558916

\begin{abstract}
One of approaches in comprehending al-Qur'an is semantic or meaning approach. There are three ways to goin the meaning; first is through microstructure, that is to get the meaning of text through structural analysis of sentence and phrase. Second, stylistic, that is the special stylistic of alQur'an to be the tool to find the meaning of the text. Third, semantic, that is the choice of word or vocabulary used in al-Qur'an has basic meaning and relational meaning. This paper is intended to observe the words that contain doa explicitly, that is the verse of doa with the key word "fi'il madhi, and amar". The research belongs to library research of qualitative approach. After analyzing the key word, the conclusions are: 1) the basic meaning of the key word in the verse of doa in al-Qur'an has lexical meaning, while the relational meaning is the meaning produced by the textual and contextual, in this case the relational meaning of the verse of doa constitutes, of synonym, antonym, and ambiguity. 2) In the verse of doa in al-Qur'an, the relational meaning is not always attached to the key words; although it is related to the other words, it sometimes still has lexical meaning.
\end{abstract}

\section{Kata Kunci}

Makna Dasar, Makna Relasional, Doa

\section{Pendahuluan}

Salah satu pendekatan yang bisa digunakan dalam upaya memahami pesan Tuhan yang terekam dalam al-Qur'an adalah dengan menggunakan pendekatan sematik atau makna. Dalam hal cara untuk mendapatkan makna Nur Kholis (2005:6) berpendapat, ada tiga jalan untuk mendapatkan makna. Pertama, melalui mikrostruktur, yakni bagaimana makna teks melalui analisis struktural kalimat dan frasa dapat dihasilkan secara maksimal. Kedua, stilistik, yakni bagaimana keistimewaan stilistik al-Qur'an dijadikan sebagai sarana untuk mendapatkan makna teks. Ketiga, semantik, bagaimana pilihan kata serta kosa kata yang dipakai al-Qur'an memiliki makna dasar dan makna relasional.

Al Qur'an sebagaimana pengakuan para ahli bahasa dan sastra merupakan fenomena kebahasaan yang sangat luar biasa yang tidak bisa terkalahkan, baik dari pemilihan kosa kata, susunan kata, struktur kalimat, gaya bahasa, dan keindahan serta lain-lainnya. Di dalam al-Quran banyak ayat-ayat yang mengandung makna doa dengan susunan dan gaya bahasa yang sangat luar biasa indahnya, dan ayat ayat tersebut sering dipakai oleh orang, khusus orang muslim untuk memohon pada Allah SWT ketika dalam kesehariannya ia sedang dalam keadaan atau situasi di luar kemampuaanya. Sebagaimana diungkapkan oleh Toshihiko Isuzu (2003:213), dalam situasi yang luar biasa, yakni pada saat manusia mendapati dirinya dalam keadaan yang tidak wajar, dalam keadaan jiwa yang tidak sebagaimana sehari-harinya, ketika karena alasan tertentu jiwa hampir berada pada titik batas, maka ia berada pada posisi dapat mengucapkan kata-kata secara langsung kepada Tuhan. Dalam situasi seperti itu, manusia tidak lagi menjadi manusia dalam pengertian yang umum, ia sudah mentrasformasikan diri menjadi sesuatu yang berada di atas dirinya. Tipe peristiwa linguistik dalam situasi di luar situasi sehari-hari ini disebut doa.

Doa dalam konteks syari'at Islam merupakan senjata paling utama dalam menghadapi segala permasalahan dalam hidup ini. Doa dalam bahasa agama mempunyai banyak istilah, yaitu: doa, dzikir, istighotsah, dan riyadhah. Bahkan, inti sholat yang dilakukan seorang muslim dalam hari, juga bermakna doa. Dalam memanjatkan doa tentunya seseorang harus benar-benar khusyuk mendekat dan memohon apa yang 
menjadi permintaannya, dan tidak jarang di antara kaum muslim ketika berdoa hanya sekedar menghafal teks doa tanpa memahami maknanya. Oleh karenanya, salah satu syarat untuk menjadikan doa itu terkabul harus benarbenar memahami makna kata dari bahasa yang diucapkan (peristiwa linguistik). Dengan demikian, memahami kata dan kosakata dalam al- Qur'an, khususnya ayat-ayat yang mengandung doa sangat mutlak diperlukan dalam kehidupan sehari-hari seorang yang beriman. Dan, salah satu cara untuk memperoleh makna kata tersebut adalah dengan pendekatan semantik yang membahas tentang makna dasar dan relasional. Dengan demikian, permasalahan utama penelitian ini adalah: apa makna dasar dan makna relasional ayat-ayat doa di dalam alQur'an? Apakah makna relasional selalu melekat pada kata kunci ayat-ayat doa di dalam al-Qur'an?

Penelitian ini tidak ingin menjelaskan seluruh kosa kata dalam ayat-ayat doa, akan tetapi difokuskan pada pengungkapan makna dasar dan relasional kosa kata penting yang menjadi kata kunci ayat-ayat yang mengandung doa secara eksplisit tersebut, yaitu ayat-ayat doa yang menggunakan kata kunci "fiil madhi dan amr".

Dalam kehidupan sehari-hari, kata makna digunakan dalam berbagai bidang maupun dalam konteks yang berbeda-beda. Kata makna biasanya sering disejajarkan dengan beberapa kosakata seperti: arti, gagasan, konsep, pernyataan, pesan, maksud, firasat, dan isi. Dari sekian kata yang disebutkan, kata arti yang mempunyai pengertian paling dekat dengan makna. (Kridalaksana, 1982:15). Namun demikian, dua kata ini tidak berarti sinonim mutlak.

Sedangkan kata makna sebagai sebagai sebuah istilah, ia mengacu pada pengertian yang sangat luas. Dari sekian banyak pengertian ini, ada sebuah pengertian tentang makna yang dikemukakan oleh Grice dan Bolinger. Menurut keduanya, makna adalah hubungan antara bahasa dengan dunia luar yang telah disepakati bersama oleh para pemakai bahasa, sehingga bisa saling dimengerti. Dari pengertian ini, berarti ada tiga unsur penting yang dimiliki makna. Pertama, makna adalah hubungan antara bahasa dengan dunia luar. Kedua, makna adalah kesepakatan pengguna bahasa. Ketiga, perwujudan makna dapat digunakan untuk menyampaikan informasi sehingga dapat saling dimengerti (Aminuddin, 1985:53).

Di antara jenis makna adalah makna dasar dan makna relasional. Jika merujuk kepada al-Qur'an sebagai sumber data dan menelaah istilah-istilah kunci di dalamnya, maka akan ditemukan dua hal, yang satu begitu nyata, dangkal, dan bisa untuk dijelaskan, sedangkan yang lain mungkin sepintas tidak begitu jelas. Sisi nyata persoalan tersebut adalah bahwa masing-masing kata individual yang diambil secara terpisah dan ia memiliki makna dasar atau kandungan kontekstualnya sendiri, maka makna kata itu bersifat menetap dan akan melekat pada kata itu, meskipun kata itu diambil dari luar konteks al-Qur'an.

Kata kitab, misalnya, makna dasarnya baik yang ditemukan dalam maupun di luar al-Qur'an adalah sama. Kata ini sepanjang dirasakan secara aktual oleh masyarakat penuturnya, ia tetap menjadi satu kata. Ia mempertahankan makna fundamentalnya yang dalam hal ini, makna yang sangat umum dan tidak spesifik. Bahwa, kata kitab dimanapun ia ditemukan, baik digunakan sebagai istilah kunci dalam sistem konsep yang ada atau yang lebih umum lagi di luar sistem khusus tersebut, ia selalu bersifat menetap. Kandungan unsur semantik ini tetap ada pada kata itu dimana pun ia diletakkan dan bagaimanapun ia digunakan, inilah disebut dengan makna dasar dari kata itu (Isuzu, 2003:11).

Sementara itu, Madigan menyatakan bahwa makna relasional adalah makna konotatif yang dalam prakteknya sangat bergantung kepada konteks sekaligus relasi dengan kosa kata lainnya dalam kalimat (Kholis, 2005:167). Kembali kepada contoh tersebut di atas. kata kitab dalam makna dasar, ketika kata ini dihubungkan dengan konsep Islam serta kemudian ditempatkan dalam hubungan erat dengan kata-kata penting alQur'an seperti Allah, wahy, tanzil dan sebagainya, maka kata kitab itu akan mengalami pengembangan dan perluasan makna yang amat berarti. Hal ini disebabkan kata yang bermakna dasar buku ini menjadi luas medan maknanya, seperti kitab suci al-Qur'an, maupun Bibel Yahudi dan Kristen ketika direlasikan dengan kata ahl dalam perbincangan al-Qur'an.

Menurut Toshihiko (2003:12), kata kitab dalam konteks karakteristik al-Qur'an harus dipahami dari segi semua istilah terkait ini. Keterkaitan itu sendiri akan memberikan kata kitab warna semantik yang sangat khusus, sangat kompleks, dan struktur makna khusus yang tidak akan pernah diperoleh jika kata itu tetap berada di luar sistem ini. Harus dicacat bahwa hal itu juga bagian dari makna kata kitab, sepanjang digunakan dalam konteks al-Qur'an, maka bagian maknanya yang sangat penting dan esensial jauh lebih penting dibandingkan makna dasar-nya sendiri. Inilah yang oleh Toshihiko disebut 
sebagai makna relasional kata untuk membedakannya dengan makna dasar.

Jadi, makna dasar kata adalah sesuatu yang melekat pada kata itu sendiri yang selalu terbawa dimanapun kata itu diletakkan. Sedangkan makna relasional adalah sesuatu yang konotatif yang diberikan dan ditambahkan pada makna yang sudah ada dengan meletakkan kata itu pada posisi khusus dalam bidang khusus dan berada pada relasi yang berbeda dengan semua katakata penting lainnya dalam sistem tersebut. Atau bisa dikatakan bahwa, relasi makna adalah hubungan semantik yang terdapat antara satuan bahasa yang satu dengan satuan bahasa lainnya. Satuan bahasa di sini dapat berupa kata, frase, maupun kalimat,. Relasi semantik itu dapat berupa kesamaan makna, pertentangan makna, kegandaan makna, atau juga kelebihan makna.

\section{Metode Penelitian}

Penelitian ini termasuk library research (penelitian pustaka) dengan pendekatan kualitatif. Dengan pendekatan ini, dimungkinkan memperoleh pengetahuan akurat dan mendalam. Penelitian ini tidak ingin menjelaskan seluruh kosa kata dalam ayat-ayat doa, akan tetapi peneliti akan membatasi pada pengungkapan makna dasar dan relasional kosa kata penting yang secara eksplisit menjadi kata kunci ayatayat yang mengandung doa.

\section{Teknik Pengumpulan Data dan Sumber Data}

Teknik pengumpulan data dalam penelitian ini, berdasarkan model penelitian yang ditentukan sebelumnya, maka teknik pengumpulan data yang digunakan adalah dokumentasi. Adapun sumber data penelitian ini dapat dibagi ke dalam dua kelompok. Pertama, data primer; yaitu sumber utama yang menjadi objek kajian penelitian ini. Data ini tidak lain adalah al-Qur'an al-Karim yang memuat banyak sekali ayat doa. Kedua, data sekunder; yaitu buku-buku literatur yang memiliki keterkaitan dan mendukung objek penelitian. Buku-buku tersebut berupa kitabkitab tafsir baik karya ulama salaf atau kholaf, semisal Tafsir al-Jalalain, Soffah al-Bayan, Soffah al-Tafaasir, dan lain sebagainya, serta berbagai buku lain yang memiliki keterkaitan dengan obyek, seperti buku tentang linguistik, semantik, sintaks, balaghah dan buku-buku lain yang mengkaji pendekatan penafsiran al-Qur'an lewat semantik.

\section{Teknik Analisis Data}

Penelitian ini didesain dengan seperangkat analisis, yaitu: a) Interpretasi, yaitu mengungkap makna yang terdapat pada ayat-ayat doa dalam rangka untuk memperoleh pemahaman yang benar. Interpretasi di sini dilakukan bukan merupakan tindakan mana suka untuk mendapatkan kepuasan berpikir belaka, tetapi sebuah usaha pemahaman yang dibangun atas dasar pencermatan secara objektif dalam rangka mencapai pemahaman yang paling akurat dan orisinil (Baker, 24-31:tt).

b) Holistik, yaitu melihat objek kajian sebagai satu kesatuan yang utuh, tidak terpisah dari setting yang melingkupinya. Ini dilakukan untuk mengenali lebih jauh terhadap objek kajian (dalam hal ini ayat-ayat doa); mencermati interrelasi dalam mikrostruktur ayat ayat doa tersebut pada satu sisi, dan juga realitas yang berada di luar (Baker:46-47:tt).

c) Historis. Dalam analisis historis ini, objek yang dipahami adalah objek yang tidak dapat terlepas dari realitas yang melingkupinya (Asbab al-Nuzul) dan mikrostruktur yang ada. Dengan kata lain, ia adalah realitas sejarah mengiringi objek dan memiliki hubungan secara kontinyu, yang baru menggantikan yang lama dan memberikan kepadanya pemaknaan baru yang relevan dengan perkembangan zaman (Baker, 47-48:tt).

d) Komparasi. Melalui analisis komparasi ini, sebuah objek dibandingkan dengan objek yang lain sehingga ditemukan gambaran yang sangat jelas (Baker, 50-51:tt).

\section{Diskusi dan Temuan}

Untuk memperoleh gambaran yang jelas tentang makna dasar dan relasional, terlebih dahulu dalam penelitian ini dipaparkan ayat-ayat dalam al-Qur'an yang memiliki makna doa secara lafdy. Adapun ayat-ayat doa yang ditemukan oleh peneliti sebanyak 28 ayat yang tersebar dalam berbagai surat. Berikut ini paparan 28 ayat doa yang terkandung di dalam al-Qur'an.

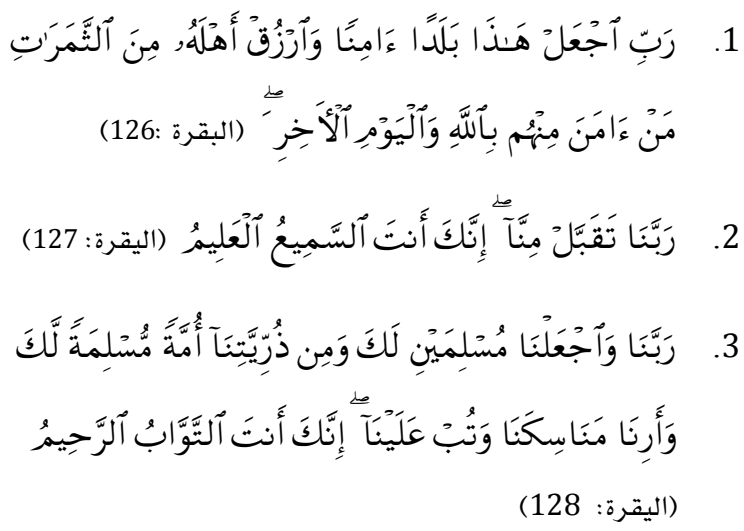




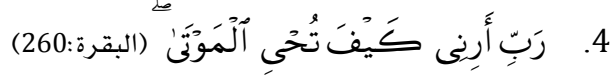

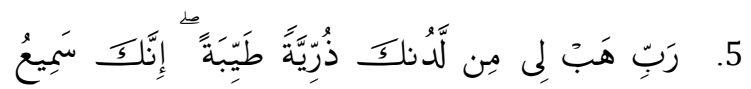

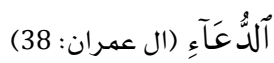

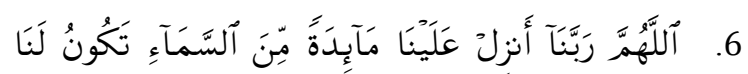

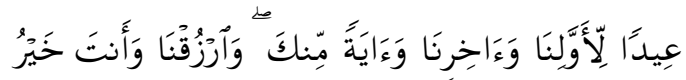

$$
\text { آكرَّزَِقِينَ (المائدة: 114) }
$$

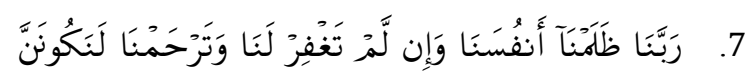

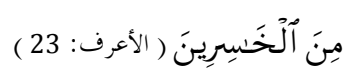

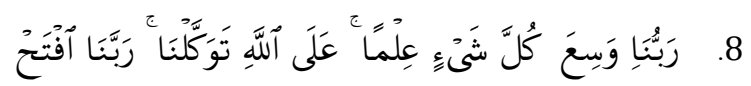

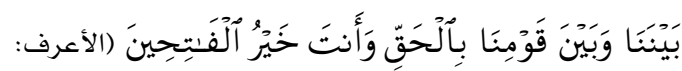

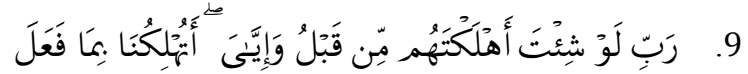

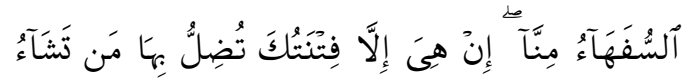

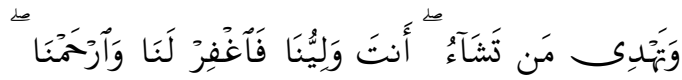

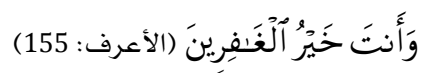

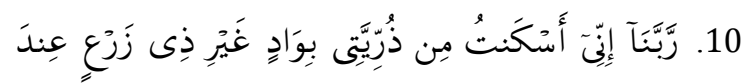

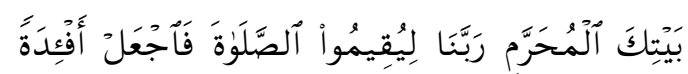

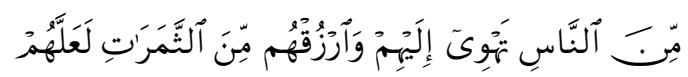

$$
\text { يَشْكُرُونَ (إبراهيم: 37) }
$$

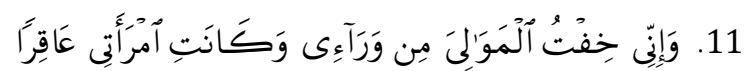

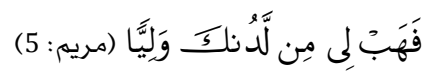

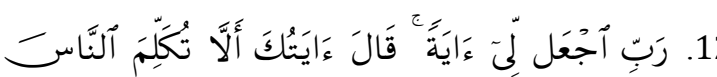

$$
\text { ثَلَنَثَ لَيَالِ سَوِيَّا (مريم: 10) }
$$

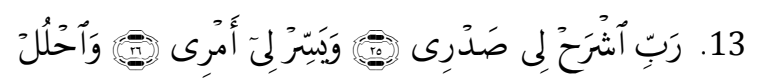

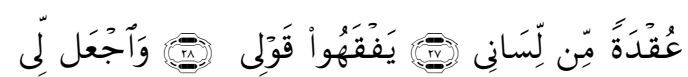

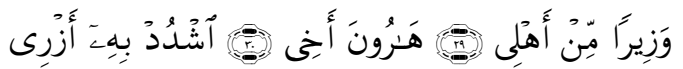

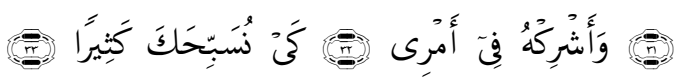

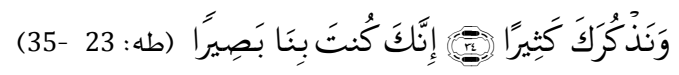

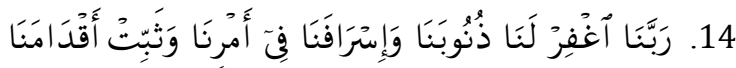
وَأنصُرَنَا عَلَى أَلْقَوْمِ آلْكَكَفِرِينَ (آل عمران: 147)

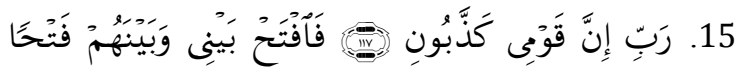

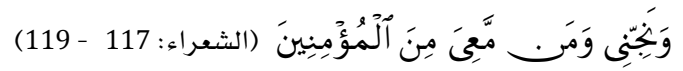

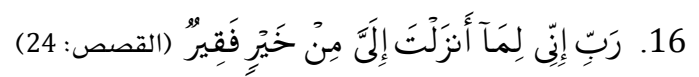

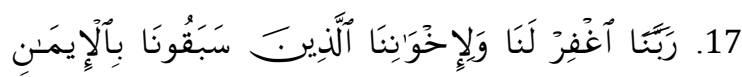

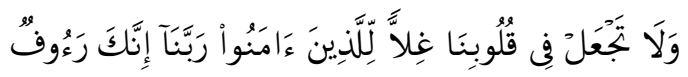

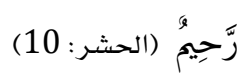

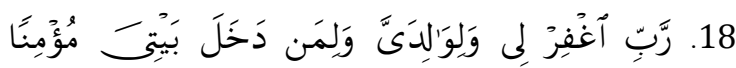

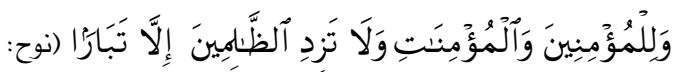

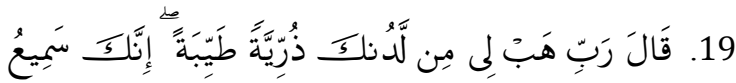
آلَدُعَآعٍ (آل عمران: 38)

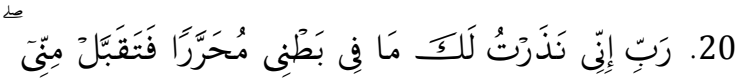

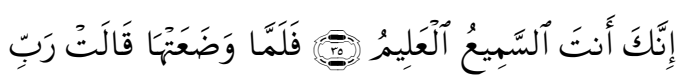

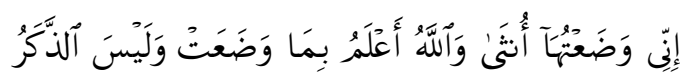

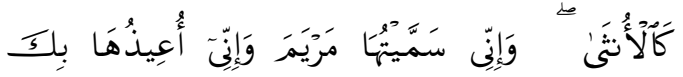

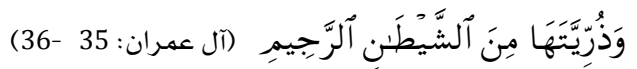

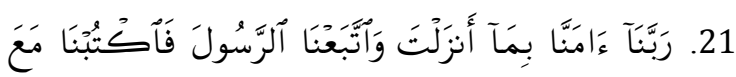

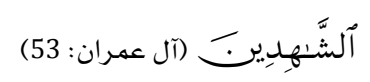

22. رَبَنَّا مَا خَلَقْتَ هَنَذا بَبطِلاً سُبْحَنَكَكَ فَفِنَا عَذَابَ

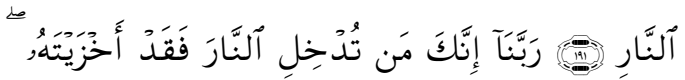




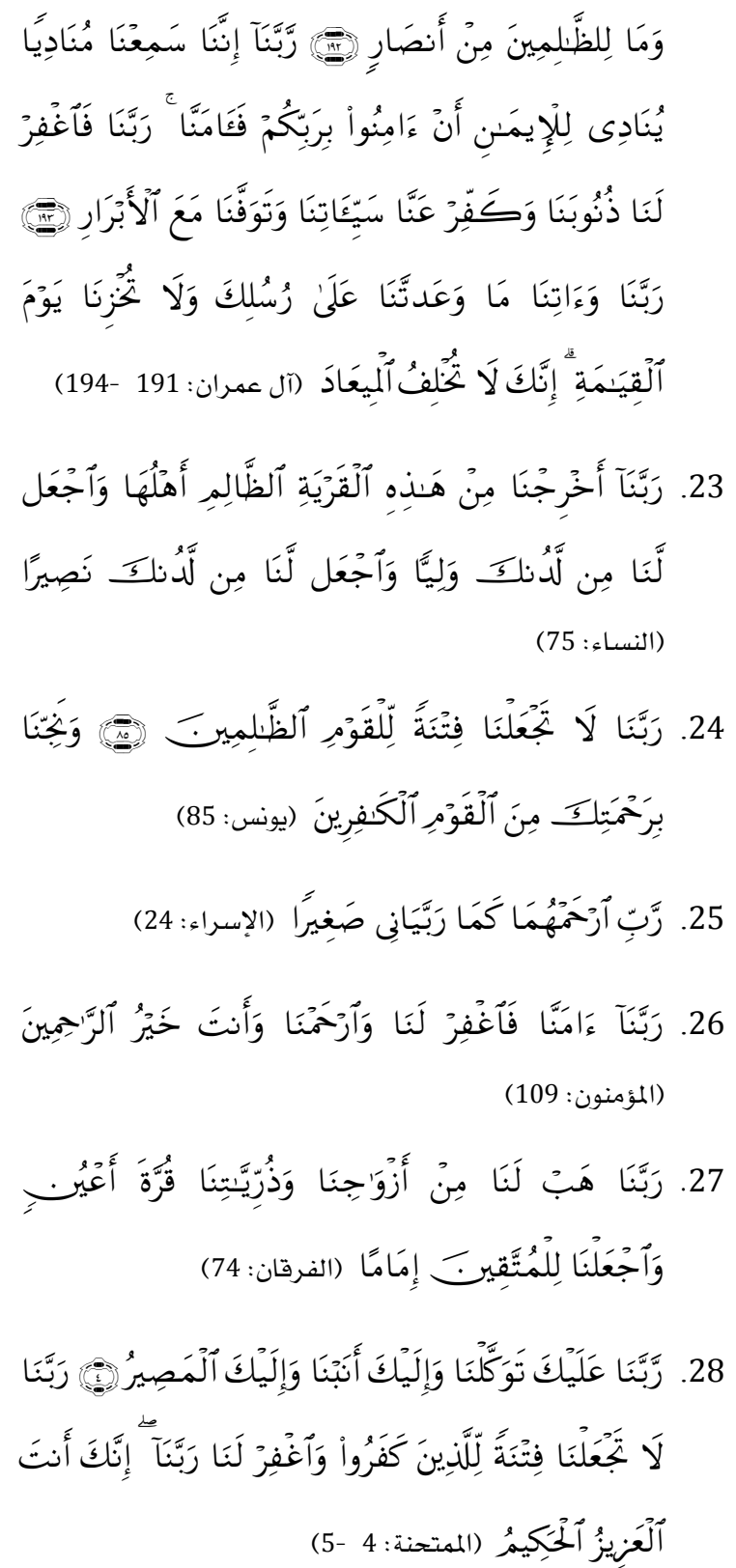

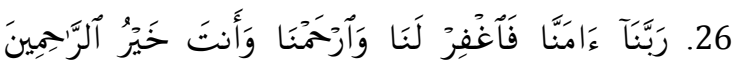

(المؤمنون: 109)

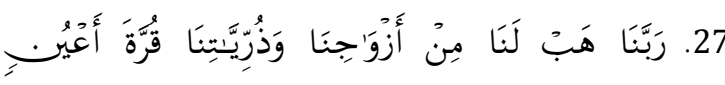

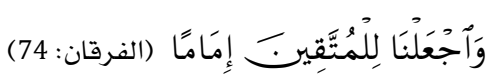

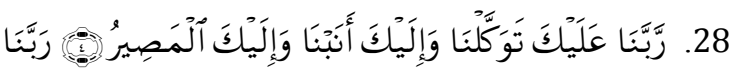

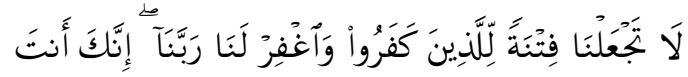

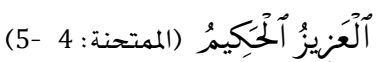

Dari paparan data di atas, untuk memperoleh makna dasar dan relasional ayat-ayat doa dalam al-Qur'an, maka analisis yang dilakukan peneliti terhadap kata-kata kunci tentang doa, khususnya yang mengandung kata kerja (fi'il). Kata kerja ini, yang utama, ia berada bentuk kata kerja perintah (amar), kemudian kata kerja yang menunjukkan pekerjaan telah dilakukan (fi'il madhi), lalu kata kerja yang sedang akan berproses (fi'il mudhari.). Adapun kata-kata kunci tersebut adalah:

\section{Kata ja'ala (جعل)}

Dalam rangkaian ayat-ayat doa di dalam alQur'an kata جعل banyak dipergunakan kurang lebih 12 kali. 11 kali dalam bentuk kata kerja perintah (amr), sedangkan 1 kali dalam bentuk kata kerja sedang dikerjakan (mudhori'). Adapun makna dasar kata جعل adalah "menjadikan", dalam perkembangan maknanya kata tersebut ketika masuk dalam sebuah teks dan berelasi dengan kata lain, maka akan ditemukan berberapa makna yang berbeda dengan makna dasar, akan tetapi kata tersebut paling banyak memiliki makna sebagaimana makna dasar yang sudah melekat.

Makna lain yang dapat dihadirkan ketika kata tersebut berelasi dengan kata lain seperti yang terdapat pada surat Ali Imron ayat 41. Kata اجعل لي dalam ayat tersebut lebih dekat artinya آية karena berelasi dengan kata اعطني dengan kata , yang artinya "berilah kami tanda". Contoh kata جعل yang berarti berilah, terdapat di dalam surat Maryam ayat 10 , al-Isra' ayat 80 , dan al-Nisa' ayat 75.

Makna lain yang juga dapat diletakkan untuk kata dasar أدخل adalah makna جعل yang bermakna dasar memasukkan. Penjelasan ini terdapat di dalam ayat doa yang terdapat pada surat alMukminun ayat 94 yang bermakna memasukkan/mengikutsertakan. Perluasan makna yang terjadi dalam hal ini, salah satunya disebabkan adanya relasi kata tersebut dengan kata القوم.

\section{Kata Araa (أرىى)}

Kata kunci kedua dalam hal doa-doa yang terdapat di dalam al-Qur'an adalah kata dasar أرى tanpa menggunakan mata kepala. Kata tersebut dapat dijumpai di dalam tiga rangkaian ayat doa. Namun demikian, dalam teks dan relasai, kata tersebut dengan kata lainnya dalam satu rangkaian ayat memberikan implikasi perluasan makna yang berbeda. Seperti kata أرنا dalam alBaqarah ayat 128 ketika Nabi Ibrahim memohon kepada Allah agar ia diberi petunjuk tentang tata cara melaksanakan ibadah haji karena kata tersebut berelasi dengan kata مناسك dan makna yang terdekat untuk kata ini adalah tunjukkanlah. Hal serupa juga terjadi dalam kalimat أرنى dalam al-Baqarah ayat 260 saat Nabi Ibrahim ingin tahu cara menghidupkan orang atau hewan yang sudah mati, akan tetapi Allah SWT membantahnya dengan kalimat: "Engkau tidak akan pernah percaya tentang hal ini". Akan tetapi, Nabi Ibrahim tetap memaksa dengan ucapannya "Tunjukkanlah padaku untuk memperkuat imanku". Dalam konteks ayat ini, kata أرنى 
berelasi dengan kata setelahnya yaitu كيف yang merupakan kata untuk bertanya yang memiliki arti bagaimana. Dalam hal ini tentunya Nabi Ibrahim meminta untuk diajari bagaimana caranya menghidupkan makhluk yang sudah mati.

Lain halnya dengan kata أرنى dalam surah al-A'raf ayat 143. Dalam ayat ini, kata tersebut memiliki makna yang lebih dekat dengan makna kesempatan karena Nabi Musa memohon kepada Allah agar Allah menampakkan diri-Nya supaya Musa bisa melihat-Nya. Tampaknya, dalam konteks ini Allah tidak memberikan kesempatan itu dan Allah hanya memberikan isyarat agar Musa melihat ke arah bukit.

Kata lain yang berasal dari kata dasar أرى ialah kata ترينى dalam surat al-Mukminun ayat 93 dan 94 yang lebih dekat maknanya dengan kata تشناهد yang berarti melihat dengan mata kepala, karena dalam konteks ini, kata tersebut merupakan permohonan untuk tidak dimasukkan ke dalam kelompok orang-orang yang memperoleh adzab ketika sedang ikut menyaksikan.

\section{Kata Taqabbala (تقبل)}

Dalam rangkaian ayat-ayat doa bisa ditemukan تقبل kurang lebih tiga ayat yang mengandung kata yang memiliki makna dasar menerima, meskipun kata tersebut telah masuk pada teks dan berelasi dengan kata lain seperti النذر ,عمل ,الدعاء dan السهبع maka akan diperoleh makna sebagaimana makna dasar yang dimiliki dan tidak mengalami perubahan dan perluasan dari makna dasarnya.

\section{Kata Wahaba (وهب)}

Kata وهب dalam rangkaian ayat-ayat doa terdapat kurang lebih tujuh kali, kata tersebut memiliki makna dasar yaitu memberi. Apabila kata tersebut masuk dalam sebuat teks dan berelasi وليا، حكما ، أزواج وذرية، : dengan kata-kata seperti ملكا، رحمة maka kata tersebut tidak mengalami perubahan makna yang signifikan. Makna yang diperoleh dari relasi kata tersebut tidak jauh dari makna dasar yang telah melekat padanya.

\section{Kata Anzala (أنزل)}

Makna dasar dari kata أنزل adalah menurunkan. Dalam rangkaian ayat-ayat doa, kata ini terdapat di dua tempat. Pertama, di surat al-Maidah ayat
114; kedua, di surat al-Mukminun ayat 93-94. Pada teks doa yang terdapat dalam ayat 114 surah al-Maidah, kata أنزل berelasi dengan kata مائدة sehingga dari hubungan kata ini tidak ditemukan pergeseran dan perubahan makna. Kata tersebut tetap bermakna turunkan.

Berbeda dengan kata أنزل di surat al-Maidah. Kata ini berelasi dengan kata مباركا sehingga implikasi yang ditimbulkan dari hubungan kata ini adalah makna yang berbeda dari makna dasar (turunkan) menjadi tempatkan, karena kata tersebut berelasi dengan kata yang artinya "tempat yang baraokah".

\section{Kata Dzalama (ظلم)}

Kata ظenjadi kata kunci pada ayat doa yang ظلم dipanjatkan Nabi Adam dan Nabi Musa. Kata dalam teks ayat doa selalu berelasi dengan kata نفس. Karenanya, maka makna yang melekat pada kata tersebut antara makna dasar dan makna relasional adalah sama, yaitu berbuat dholim.

\section{Kata Ghafara (غفر)}

Kata غفر menjadi kata kunci dalam ayat-ayat doa di dalam al-Qur'an dan digunakan kurang lebih dalam 28 ayat. Meskipun kata ini banyak dipergunakan dalam rangkaian ayat-ayat doa dan berelasi dengan kata lain seperti kata ganti atau dhomir لنا dan lain sebagainya, kata ini tidak mengalami perubahan dan tetap memiliki makna sebagaimana makna dasar yang telah melekat sebelumnya, yaitu pengampunan. Jadi, tidak ada perbedaan antara makna dasar dan makna resalional untuk kata ini.

\section{Kata Fataha (فتح)}

Kata فتح memiliki makna dasar membuka. Sedangkan dalam rangkaian ayat-ayat doa, kata فتح berada dalam dua surat, yaitu surat al-A'raf ayat 89 dan surah al-Syuara' ayat 117-118. Kata tersebut keduanya berelasi dengan kata بين Dilihat dari relasi kata tersebut, dihasilkan makna yang berbeda dengan makna dasar yang sudah melekat pada kata tersebut, berupa makna baru yang berarti keputusan, sebagaimana yang tercantum dalam kedua ayat tersebut. 


\section{Kata Rahima (رحم)}

Dalam rangkaian ayat-ayat doa di dalam alQur'an, kata رحم yang mempuyai makna dasar rahmat (belas kasih), terdapat 5 ayat yang menggunakan kata tersebut. Kata tersebut dalam teks ayat-ayat doa selalu didahului oleh kata غفر. Relasi kata tersebut dalam rangkaian teks dengan kata lain menimbulkan penambahan penjelasan terhadap makna dasar. Kata tersebut memiliki arti: "rahmat agar tidak melakukan dosa pada kemudian hari setelah memperoleh ampunan".

Uraian di atas merupakan beberapa fakta adanya hubungan kata dengan kata lain dalam satu teks yang akhirnya dapat melahirkan makna baru yang lebih tepat. Tentunya, masih banyak lagi kata kunci doa-doa di dalam al-Qur'an yang bisa dijelaskan lewat kajian semantik.

\section{Penutup}

Setelah dilakukan analisa terhadap kata-kata kunci dalam ayat-ayat doa yang berada di dalam al-Qur'an yang terbatas pada pespektif makna dasar dan makna relasional, maka diperoleh simpulan hasil sebagai berikut. Pertama, makna dasar kata kunci ayat-ayat doa di dalam al-Qur'an tidak banyak mengalami perubahan. Kata-kata tersebut sesuai makna leksikal yang dimilikinya. Sedangkan makna relasional dari kata-kata kunci yang terdapat ayat-ayat doa di al-Qur'an terjadi dalam bentuk seperti: kesamaan makna, pertentangan makna, kegandaan makna. Kedua, ayat-ayat doa di dalam al-Qur'an, makna relasionalnya tidak selalu melekat pada kata kunci doa yang terdapat pada ayat-ayat tersebut. Meskipun telah berelasi dengan kata lain, kata tersebut terkadang tetap bermakna sebagaimana makna dasar.

Oleh karenanya, dalam usaha memahami ayatayat al-Qur'an, terutama ayat-ayat doa yang seringkali dibaca, sebaiknya selalu mempertimbangkan makna yang ditimbulkan oleh hubungan kata dengan kata lainnya yang berada dalam satuan teks dan konteks ayat-ayat tersebut, sebab ternyata sebuah kata yang terdapat di dalam ayat-ayat doa tersebut tidak selalu memiliki makna sebagaimana makna dasar atau aslinya.

\section{DAFTAR PUSTAKA}

Al-Khouli. M. Ali. 1982. Asaliib Tadris al-Lughoh al-Arabiyah. Riyadh: Maktabah Al-Arabiyah AlSaudiyah.

Al-Sayuthi, Jalaluddin dan Jalaluddin al-Mahally. Tanpa tahun. Tafsir Jalalain. Maktabah al-Syamilah al-Islamiyah al- Elektroniyah

Al-Shobuni, Muhammad Ali. Tanpa tahun. Mukhtashor Tafsir Ibn Kastir. Maktabah as Syamilah al Islamiyah al Eletroniyah

Aminuddin. Tanpa tahun. Semantik Pengantar Studi Tentang makna. Bandung: Sinar Baru Algensindo.

Anany, Muhammad. 2003. Nadhoriyah al-Tarjamah al-Haditsah: Madkhol Ila Mabhats Dirosah alTarjamah. Kairo: al-Syarikah al-Misriyah al-Alamiyah Li al-Nasyr.

Baker, Anton dan Achmad Charis Zubair. Tanpa tahun. Metodologi Penelitian Filsafat. Yogyakarta: Kanisius.

Departemen Agama RI. 1992 . Al-Qur'an dan Terjemahan. Semarang: P.T. Tanjung Mas Inti.

Isuzu, Thosihiko. 2003. Relasi Tuhan dan Manusia. Yogyakarta: P.T. Tiara Wacana.

Kholis, M. Nur Setiawan. 2005. Al-Qur'an Kitab Sastra Terbesar. Yogyakarta: Elsaq.

Laksana, Krida Harimurti. 1988, Pengantar Linguistik Umum. Yogyakarta: Gajah Mada University Press.

Munawir, Ahmad Warson. 1984. Kamus Al Munawir Arab-Indonesia Terlengkap. Surabaya: Pustaka Progresif.

Newmark, Peter. 1981. Approaches to Traslation. Oxford: Pergamon Press. 
Palmer, F.R. 1981, Semantics, London: Cambridge University Press.

Rahardjo, Mudjia. 2005. Mengungkap Tabir di Balik Makna. Makalah Seminar Fakultas Humaniora dan Budaya UIN Malang.

Sapir, E. 1921. Language. Harcaourt. Brace and Warld

Sudarmaji, 2005. Ensiklopedi Ringkas al-Qur'an Jilid 2. Jakarta: Lintas pustaka,

Syamsuddin, Syahiron. 2004. Prinsip dan Dasar Hermeneutika al Qur'an Kontemporer. Yogyakarta: Elsaq.

Toyib. 2005. Analisis Makna. Makalah Seminar Nasional "Menyingkap Tabir Makna di Balik Makna". Fakultas Humaniora dan Budaya UIN Malang.

Verhaar, J.W.M. 2001. Azas-Azas Linguistik Umum. Yogyakarta: Gajah Mada University Pres.

Verhaar, J.W.M. 2001. Azaz-Azas Linguistik Umum. Yogyakarta: Gajah Mada Universitas Press.

Wahab, Abdul. 1995. Teori Semantik. Surabaya: Airlangga University Press.

Yusuf, Suhendra. 1994. Teori Terjemah Pengantar ke Arah Pendekatan linguistik dan Sosiolinguistik. Bandung: Mandar Maju. 